\title{
Manajemen Sarana Prasarana di Sekolah Dasar Negeri 1 Kota Prabumulih
}

\author{
Restika Manurung1, Edi Harapan', Tahrun¹, Aris Suharyadi² \\ ${ }^{1}$ Universitas PGRI, Palembang, Sumatera Selatan, Indonesia \\ 2Universitas Negeri Yogyakarta, Yogyakarta, DIY, Indonesia
}

Corresponding author: Restika Manurung (e-mail: restikamanurung1@gmail.com)

\begin{abstract}
Abstrak: Pada saat ini, salah satu faktor yang menentukan mutu pendidikan di Indonesia adalah sarana dan prasarana. Sarana dan prasarana pendidikan dapat membantu siswa belajar dengan nyaman. Penelitian ini bertujuan untuk mendeskripsikan manajemen sarana dan prasarana di Sekolah Dasar (SD) Negeri 1 Prabumulih, kendala yang dihadapi, dan solusi untuk mengatasi kendala tersebut. Penelitian ini menggunakan pendekatan kualitatif. Pengumpulan data dilakukan dengan wawancara, observasi, dan dokumentasi. Responden penelitian ini adalah kepala sekolah, guru, dan staf tata usaha. Hasil penelitian menunjukkan bahwa pengadaan sarana dan prasarana memprioritaskan pembangunan sanitasi. Manajemen sarana prasarana yang meliputi perencanaan, pengadaan, penggunaan, pemeliharaan, dan penghapusan sarana prasarana telah berjalan dengan baik. Kendala yang dihadapi yaitu kurangnya dana yang diperlukan untuk proses pengadaan dan kurangnya tenaga tata usaha dalam proses pengelolaan manajemen sarana dan prasarana.
\end{abstract}

Kata Kunci : sarana dan prasarana pendidikan, manajemen sarana prasarana pendidikan

\section{Educational Facilities Management at Prabumulih 1 State Elementary School}

\begin{abstract}
One of the factors that determine the quality of education in Indonesia is the facilities and infrastructure. Educational facilities and infrastructure can help students learn comfortably. This study aims to describe the management of facilities and infrastructure in Prabumulih 1 State Elementary School, the obstacles faced, and solutions to overcome these obstacles. This research uses a qualitative approach. Data collection was carried out by interview, observation, and documentation. Respondents of this study were school principals, teachers, and administrative staff. The results showed that the procurement of facilities and infrastructure prioritized sanitation development. Infrastructure management, which includes planning, procurement, use, maintenance, and infrastructure elimination, has been going well. The obstacles faced are the lack of funds required for the procurement process and the lack of administrative personnel in managing facilities and infrastructure.
\end{abstract}

Keywords: educational facilities, educational facilities management 


\section{PENDAHULUAN}

Pendidikan merupakan investasi penting dan memiliki peranan strategis bagi terwujudnya sumber daya manusia yang berkualitas (Irwandani et al., 2017). Selain itu, pendidikan memiliki peran sentral bagi upaya pengembangan sumber daya manusia (Abidin, 2017). Semakin jelas pendidikan itu, maka semakin tampak pula perkembangan dan kemajuan suatu bangsa. Sistem pendidikan harus mampu menjamin peningkatan mutu, relevansi dan efisiensi manajemen pendidikan (Setiawan, 2016). Penyelenggaraan program pendidikan di sekolah tidak akan terlepas dari konsep manajemen pendidikan (Nur et al., 2018) dimana sekolah sebagai sebuah lembaga pendidikan yang menyelenggarakan proses belajar mengajar (Bafadal, 2018). Oleh karena itu kualitas suatu lembaga pendidikan tidak hanya ditentukan oleh kualitas pembelajaran semata, namun juga dipengaruhi bagaimana lembaga pendidikan tersebut mampu mengelola sumber daya manusianya (Komariah, 2018).

Sekolah dan madrasah, merupakan sebuah lembaga pendidikan sebagai tempat berlangsungnya atau dilaksanakannya kegiatan pendidikan (Saebani \& Ahmad, 2012). Salah satu komponen yang sangat menentukan untuk terselenggaranya proses pendidikan adalah guru yaitu sebagai fasilitator dalam proses pembelajaran (Mulyani, 2012). Dalam penyelenggaraan pendidikan untuk menghasilkan proses belajar mengajar yang efektif dan efisien maka dibutuhkan sarana dan prasarana (Awaludin \& Saputra, 2017). Peralatan yang berupa gedung, perpustakaan, dan alat-alat yang digunakan ketika belajar di kelas sangat erat hubungannya dengan mutu sekolah (Tafsir, 2010). Apalagi bila menggunakan alat-alat peraga, alat bantu seperti dalam pengajaran fisika, biologi, anatomi, atau geografi (Kristiawan, 2017). Prasarana merupakan alat tidak langsung yang berfungsi untuk mencapai tujuan dalam pendidikan, diantaranya lokasi, tempat, bangunan sekolah, sedangkan sarana seperti alat langsung yang berfungsi mencapai tujuan pendidikan, diantaranya ruangan, buku, perpustakaan, laboratorium (Darmawan, 2016).

Proses pendidikan memang memerlukan fasilitas atau peralatan, dan semua peralatan atau fasilitas harus diadakan sesuai dengan kebutuhan. Menurut Ananda dan Banurea (2017), ada dua jenis pemeliharaan sarana dan prasarana di sekolah, yakni pemeliharaan sehari-hari dan pemeliharaan secara berkala. Pemeliharaan sehari-hari biasanya dilakukan oleh staf yang diserahi tugas dan tanggung jawab terhadap fasilitas tersebut. Misalnya untuk mesin-mesin praktik di SMK yang setiap hari selalu harus dirawat agar kinerjanya tetap terjaga ketika digunakan siswa. Pemeliharaan berkala (periodic maintenance) adalah pemeliharaan yang dilakukan secara berkala sesuai dengan jadwal yang telah diprogramkan. Pembuatan jadwal itu 
berdasarkan kepentingan perlakuan terhadap objek pemeliharaan misalnya keperluan penggantian oli seharusnya berapa jam kerja, penyetelan ulang bagian-bagian yang bergerak setiap berapa bulan dan sebagainya. Di dalam pemeliharaan berkala ini kita kenal adanya pemeliharaan mingguan, bulanan, dan tahunan.

Kegiatan yang dilakukan untuk memantau sarana prasarana sekolah adalah evaluasi. Menurut Ika (2015), mengatakan proses evaluasi sarana dan prasarana adalah suatu proses mengumpulkan dan menyajikan informasi untuk pertimbangan dalam pengambilan keputusan terhadap sarana dan prasarana yang digunakan. Melalui cara ini akan diketahui sarana atau prasarana mana saja yang perlu dilakukan perbaikan, pembelian baru, atau penghapusan.

Kriteria minimum yang yang harus dimiliki oleh sekolah formal baik dari Sekolah Dasar/Madrasah Ibtidaiyah (SD/MI), dan khususnya di SD Negeri 1 Prabumulih meliputi ruang kelas, ruang perpustakaan, ruang laboratorium komputer, ruang laboratorium MIPA, ruang pimpinan, ruang guru, ruang tata usaha, tempat beribadah, ruang konseling, ruang UKS, ruang organisasi kesiswaan, jamban, gudang, ruang sirkulasi, dan tempat berolahraga. Selama ini kegiatan manajemen sarana prasarana belum dilakukan secara konsisten mengingat dari tahun ke tahun kegiatan manajemen sarana prasarana terkesan hanya mengalir mengikuti alur tahun sebelumnya. Terdapat fungsi manajemen yang tidak dilakukan karena keterbatasan waktu dan biaya. Selain itu jarangnya keterlibatan warga sekolah dalam proses pengadaan menjadi salah satu permasalahan yang ada dalam manajemen sarana prasarana di sekolah ini.

Penelitian ini bertujuan mendeskripsikan kegiatan manajemen sarana dan prasarana yang dilakukan oleh SD Negeri 1 Prabumulih, kendala apa saja yang dihadapi dalam proses implementasi, serta solusi yang dilakukan dalam mengantisipasi kendala yang ada.

\section{METODE PENELITIAN}

Penelitian ini menggunakan metode penelitian kualitatif. Menurut Sujarweni (2014), penelitian kualitatif adalah jenis penelitian yang menghasilkan penemuan-penemuan yang tidak dapat dicapai dengan menggunakan prosedur-prosedur statistik atau cara-cara lain dari kuantifikasi (pengukuran). Data kualitatif diperoleh melalui teknik pengumpulan data yakni wawancara, analisis dokumen, diskusi terfokus, atau observasi yang telah dituangkan dalam catatan lapangan (Dady, Ilat, \& Pontoh, 2017). Pada hakikatnya penelitian deskriptif kualitatif merupakan suatu metode dalam meneliti status sekelompok manusia, suatu objek dengan tujuan membuat deskriptif, gambaran atau lukisan secara sistematis, faktual dan akurat mengenai fakta atau fenomena yang diselidiki (Convelo, et al., 2013). 
Penelitian ini dilakukan di SD Negeri 1 Kota Prabumulih dengan alamat Jalan Jendral Sudirman No. 234 Prabumulih Desa Prabumulih, Kecamatan Prabumulih Barat, Kota Prabumulih Sumatera Selatan. Adapun waktu penelitian ini dilaksanakan mulai dari tanggal 12 Oktober sampai dengan 19 Juni 2020. Informan penelitian didasarkan pada pertimbangan bahwa informan penelitian dapat memberikan informasi yang lengkap, mendalam, dan relevan dengan tujuan penelitian (Rukayat, 2017). Adapun informan dalam penelitian ini meliputi guru, staf, dan kepala sekolah.

Teknik pengumpulan data pada penelitian ini menggunakan wawancara, observasi, dan dokumentasi. Sugiyono (2010) mengemukakan bahwa yang perlu dipegang oleh peneliti dalam menggunakan metode interview dimana obyek (responden) yaitu orang yang paling tahu tentang dirinya sendiri, apa yang dinyatakan oleh subyek kepada peneliti adalah benar dan dapat dipercaya, dan interpretasi subyek tentang pertanyaan-pertanyaan yang diajukan peneliti kepadanya adalah sama dengan apa yang dimaksudkan oleh peneliti.

Observasi pada penelitian ini dilakukan untuk menggali dan mengkonfirmasi data yang telah didapatkan melalui interview. Beberapa hal yang dapat digali melalui observasi adalah sebagai berikut:

Tabel 1. Topik yang Digali Melalui Observasi

\begin{tabular}{ll}
\hline No & Topik \\
\hline 1. & Perencanaan : \\
& Rencana kebutuhan sarana prasarana \\
& Rapat perencanaan sarana prasarana \\
$2 . \quad$ & Pengorganisasian \\
& Deskripsi kerja pengelolaan sarana prasarana \\
& Struktur organisasi pengelolaan sarana prasarana \\
3. & Pelaksanaan \\
& Suasana kegiatan pembelajaran siswa \\
& Sarana prasarana sekolah \\
& Ruang kelas serta sarana prasarana \\
& Pengontrolan \\
& Penghapusan sarana prasarana \\
& Inventarisasi sarana prasarana \\
\hline
\end{tabular}

Selain wawancara dan observasi, teknik pengumpulan data yang digunakan dalam penelitian ini menggunakan studi dokumentasi. Teknik ini berfungsi untuk mendokumentasikan pegelolaan sarana dan prasarana di SD Negeri 1 Kota Prabumulih meliputi: 
Tabel 2. Topik yang digali melalui Dokumentasi

\begin{tabular}{|c|c|}
\hline No & Objek Dokumentasi \\
\hline 1. & $\begin{array}{l}\text { Pengorganisasian : } \\
\text { Tugas dan Wewenang } \\
\text { Penyusunan struktur organisasi }\end{array}$ \\
\hline 2. & $\begin{array}{l}\text { Perencanaan : } \\
\text { Penyusunan rencana kebutuhan } \\
\text { Rapat perencanaan }\end{array}$ \\
\hline 3. & $\begin{array}{l}\text { Pengontrolan : } \\
\text { Penghapusan sarana prasarana } \\
\text { Inventarisasi sarana prasarana }\end{array}$ \\
\hline 4. & $\begin{array}{l}\text { Pelaksanaan : } \\
\text { Pemeliharaan sarana prasarana } \\
\text { Pengadaan sarana prasarana }\end{array}$ \\
\hline
\end{tabular}

Setelah data terkumpul, data dianalisis melalui proses reduksi data, display dan verification (Miles and Huberman, 1992). Dalam penelitian ini, teknik yang digunakan untuk menganalisa data yang telah diperoleh dengan cara deskriptif (non statistic), yaitu penggambaran data yang telah diperoleh dengan kata-kata atau kalimat yang dipisahkan menurut kategori untuk memperoleh suatu kesimpulan. Dalam penelitian ini triangulasi yang digunakan adalah triangulasi sumber data yaitu kepala sekolah, guru, dan tenaga staf tata usaha di SD Negeri 1 Prabumulih, dimana proses triangulasi ini mengarahkan penelitian supaya pada saat proses pengumpulan data dan peneliti wajib menggunakan data-data yang ada secara beragam.

\section{HASIL}

Fase perencanaan sarana prasarana di SD Negeri 1 Prabumulih adalah langkah untuk menetapkan kebutuhan sarana prasarana berdasarkan kondisi yang dimiliki. Fase perencanaan melalui beberapa rangkaian kegiatan seperti rapat koordinasi sekolah, penetapan program sekolah, dan penetapan kebutuhan sarana prasarana sekolah. Rapat koordinasi sekolah harus dihadiri kepala sekolah, guru, serta staf TU. Proses rapat koordinasi dipimpin oleh kepala sekolah dan dilanjutkan dengan guru dan staff TU yang saling memberi masukan agar mencapai kesepakatan. Menurut Ibu MS, selaku Kepala SD Negeri 1 Prabumulih pada tanggal 16 Juni 2020, yang menyatakan bahwa :

"Proses perencanaan dimulai dengan merencanakan apa saja kebutuhan. Proses ini dilaksanakan dengan mengadakan rapat koordinasi dengan guru-guru serta staff dengan waktu sekali setahun diawal semester.Untuk tahun ini, program yang akan kita kerjakan yaitu membangun sanitasi sekolah yang masih minim pada saat ini, karena itu merupakan sarpras yang sangat dibutuhkan dan sangat vital bagi warga sekolah." 
Fase pengorganisasian sarana dan prasarana (organizing) yang dilakukan oleh pihak sekolah berdasarkan data dokumentasi yang diperoleh adalah diketahui struktur rancangan pengelolaan serta job description yang disesuaikan menurut Surat Keputusan Kepala Sekolah No 427/2019 tentang Penjatahan Tugas SD Negeri 1 Prabumulih serta detail dari setiap tugas yang diberikan. Pada Surat Keputusan itu, terdapat penjelasan tentang staff maupun guru.

Fase selanjutnya adalah pengadaan. Pengadaan di SD Negeri 1 Prabumulih dilakukan dengan mengidentifikasi kebutuhan yang akan diadakan. Saat penelitian dilakukan, yang menjadi prioritas sekolah adalah sanitasi sekolah. Menurut Kepala Sekolah pada tanggal 16 Juni 2020, dijelaskan bahwa :

"setelah direncanakan, kami biasanya memetakan kebutuhan sekolah tau bahasa akademiknya menganalisis kebutuhan. Kalau rencana tadi kan berbasis pengalaman terdahulu, nah kalau sekarang kita fokus pada kebutuhan sekolah. Sebenarnya ada beberapa sumber dana yang kita dapatkan untuk sekolah setiap tahun, karena kita dapat dana dari donatur dan BOS, Jadi disesuaikan kebutuhan yang ada. Jika belum perlu, maka ditunda dahulu..."

Fase pemeliharaan sarana prasarana di lingkungan SD Negeri 1 Prabumulih berfungsi untuk menjaga agar sarana dan prasarana di sekolah awet. Melalui pemeliharaan yang rutin akan dapat menghemat pengeluaran untuk mengganti sarana prasarana yang dapat rusak apabila tidak dipelihara. Pada akhirnya dana dapat dialihkan ke kebutuhan lainnya yang lebih mendesak. Selama ini pemeliharaan dilakukan oleh staf, dimana staf tersebut bertanggung jawab langsung terhadap kepala TU. Menjaga kebersihan sarana prasarana setiap hari dilakukan oleh staf kebersihan. Kegiatan tersebut merupakan salah satu kegiatan rutin yang dilakukan oleh pihak sekolah agar sarana prasarana tetap dalam keadaan baik.

Proses penghapusan sarana prasarana di SD Negeri 1 Prabumulih dilaksanakan dengan menghapus barang yang sudah usang supaya tidak terjadi penumpukan barang sehingga kurangnya ruang atau tempat penyimpanan. Penjualan barang dan pemilihan barang merupakan fase penghapusan di SD Negeri 1 Prabumulih. Penghapusan dilakukan oleh sekolah sendiri. Berdasarkan wawancara dengan salah satu staf menyebutkan bahwa biasanya penghapusan barang dilakukan internal yakni dengan mengumumkannya di grup WhatsApp terlebih dahulu sehingga apabila terdapat warga sekolah yang kemungkinan membutuhkan dapat membelinya dengan harga yang relatif terjangkau.

Fase inventarisasi di SD Negeri 1 Prabumulih dilakukan berdasarkan keputusan Tenaga Kependidikan Departemen Pendidikan Nasional tahun 2007 dan Direktorat Jenderal Peningkatan Mutu Pendidik. Kegiatan ini sudah memiliki semacam SOP tersendiri sehingga hanya tinggal mengikuti aturan dan prosedur. Kegiatan inventarisasi dilakukan dengan proses 
pengecekan kondisi barang dan menghitung barang yang terdapat di sekolah. Terakhir adalah dengan membuat laporan mengenai jumlah dan keadaan sarana prasarana kepada dinas pendidikan.

Berdasarkan pemaparan hasil informasi melalui wawancara, dokumentasi, dan observasi tersebut diperoleh informasi tentang beberapa masalah. Pertama mengenai perbaikan serta perawatan sarana prasarana yang memerlukan dana relatif besar sehingga terkadang rencana tahun sebelumnya masih kurang. Selanjutnya mengenai kurangnya tenaga tata usaha yang paham mengenai regulasi terkait sarana prasarana karena minimnya pelatihan yang diselenggarakan oleh dinas.

\section{PEMBAHASAN}

Berdasarkan hasil penelitian, maka implementasi manajemen sarana prasarana di SD Negeri 1 Prabumulih memiliki empat fase yaitu perencanaan, pengorganisasian, pelaksanaan, dan pengontrolan. Fase perencanaan merupakan awal dari setiap kegiatan, termasuk dalam manajemen sarana prasarana. Perencanaan yang baik akan mengantisipasi masalah yang dapat ditimbulkan misalnya kesalahan pembelian ataupun pemborosan (Suharyadi \& Jabar, 2016). Proses perencanaan sarana prasarana diawali dengan melakukan rapat koordinasi. Rapat ini dilakukan setiap awal semester dengan melibatkan perwakilan dari beberapa unsur yakni pihak internal maupun eksternal. Internal diwakili oleh para guru dan eksternal biasanya dihadiri oleh komite sekolah (Asiabaka, 2008). Melalui kegiatan tersebut dapat ditetapkan prosedur kerja untuk mengadakan sarana prasarana yang dibutuhkan.

Pengorganisasian dalam kegiatan manajemen sarana prasarana memiliki dipimpin oleh kepala sekolah ataupun koordinator. Pada sekolah ini koordinator sarpras yang melakukan pengorganisasian meliputi mengelola kebutuhan sarana dan prasarana dan melaporkan hasilnya ke kepala sekolah. Koordinator ini tentu juga akan mempertanggung jawabkan pekerjaannya kepada pimpinan tertinggi di sekolah yaitu kepala sekolah. Peran kepala sekolah penting karena tugasnya memastikan kegiatan strategis sarana prasarana sekolah lancar. Fase pelaksanaan dalam konteks ini adalah proses pengadaan sarana prasarana yang sudah diputuskan sebelumnya oleh rapat pleno yang melibatkan berbagai unsur (Torlakson, 2011). Kepala sekolah dan bendahara melaporkan kepada koordinator sarana prasarana agar segera membeli atau membuat tender untuk barang yang menjadi kebutuhan.

Fase inventarisasi dilaksanakan berdasarkan peraturan atau regulasi yang sudah ditetapkan oleh dinas pendidikan terkait sehingga pihak sekolah hanya tinggal mengikuti prosedur agar proses inventarisasi sarana prasarana sesuai standar. Aplikasi terbaru yang 
dikembangkan oleh kementerian pendidikan dan kebudayaan juga saat ini telah mengakomodir kepentingan inventarisasi yaitu aplikasi dapodik. Kendala-kendala saat pelaksanaan perencanaan adalah bahan-bahan untuk kepentingan analisis kebutuhan masih sangat terbatas sehingga belum optimal dalam merencanakan sarana prasarana selama ini. Pada aspek pengorganisasian adalah beberapa staf yang diserahi tugas belum melaksanakannya dengan tupoksi masing-masing. Dalam hal pelaksanaan adalah masih kurangnya sumber dana dalam proses pelaksanaan implementasi sarana prasarana di SD Negeri 1 Prabumulih, serta tenaga administrasi yang kurang personil (khususnya personil dalam pengelolaan sarana dan prasarana).

\section{KESIMPULAN}

Implementasi manajemen sarana prasarana di SD Negeri 1 Prabumulih sudah dilaksanakan dengan cukup baik dalam hal merencanakan, mengadakan, memelihara, serta menginventarisasi sarana prasarana yang ada di dalam lingkungan sekolah tersebut. Kendalanya yaitu ada kekurangan di bagian dana dan tenaga tata usaha. Solusi yang telah dilakukan SD 1 Prabumulih untuk menyelesaikan masalah yang ada yaitu: 1. Pengadaan harus sesuai dengan Rancangan Kerja Sekolah yang telah disusun, 2. Pengorganisasian harus dilakukan sesuai dengan tupoksi sekolah, 3. Pengontrolan pengadaan dan penggunaan sarana prasarana harus dilaksanakan dengan prosedur yang telah diputuskan sebelumnya, sehingga dokumen pendukung lengkap. Peran dari setiap stakeholder menentukan mutu pendidikan dari sisi sarana prasarana di SD Negeri 1 Prabumulih. Misalnya, orang tua siswa tidak hanya berperan dalam dukungan dana atau sumbangan fisik saja, tetapi harus bisa lebih. Peran serta masyarakat sudah dianggap baik jika terlibat di dalam bidang pengelolaan sekolah. Hendaknya untuk penelitian lebih lanjut kedepannya, lebih diharapkan pendapat dari seluruh unsur seperti penjaga sekolah agar dapat mewujudkan total quality manajemen pendidikan di SD Negeri 1 Prabumulih.

\section{Acknowledgement}

Terimakasih sebesar-besarnya kepada pihak-pihak yang telah membantu saya dalam proses penelitian ini. Selain itu, terimakasih juga kepada Kepala Sekolah SD Negeri 1 Prabumulih atas ketersediaan datanya beserta guru dan staff yang bekerja didalamnya. 


\section{DAFTAR PUSTAKA}

Abidin, A. A. (2017). Manajemen pembiayaan pendidikan tinggi dalam upaya peningkatan mutu (Studi kasus pada perguruan tinggi swasta menengah di Surabaya). Jurnal Penjaminan Mutu, 3(1), 87-99.

Ananda, R., \& Banurea, O. K. (2017). Manajemen sarana dan prasarana pendidikan. Bandung: Rosdi Karya

Asiabaka, I. P. (2008). The need for effective facility management in schools in nigeria. New York Science Journal, 10, 10-21

Awaludin, A., \& Saputra, E. (2016). Sistem informasi manajemen sarana prasarana sekolah (studi kasus: dinas pendidikan dan kebudayaan kabupaten siak). Jurnal Ilmiah Rekayasa dan Manajemen Sistem Informasi, 2(2), 6-13.

Bafadal, I. (2018). Manajemen implementasi kurikulum dan pembelajaran berbasis tauhid dalam pembentukan karakter peserta didik. Jurnal Adminitrasi dan Manajemen Pendidikan, 1(2), 188-197.

Convelo G. Cevilla, et al,. (2013). Pengantar metode penelitian. Jakarta: Universitas Indonesia.

Dady, F., Ilat, V., \& Pontoh, W. (2017). Analisis sistem akuntansi dan prosedur pembayaran klaim jaminan kematian pada pt. taspen (persero) cabang manado. Jurnal Riset Akuntansi Going Concern, 12(1), 63-72.

Darmawan, B. (2016). Pengaruh layanan pembelajaran, sarana-prasarana, kerjasama institusi, dan pemasaran lulusan terhadap kepuasaan siswa. Jurnal Administrasi Pendidikan, 23(1).

Irwandani, dkk. (2017). Modul digital interaktif berbasis articulate studio'13 : pengembangan pada materi gerak melingkar kelas x. Jurnal Ilmiah Pendidikan Fisika Al-Biruni, 06(2), 221-231. https://doi.org/10.24042/jipfalbiruni.v6i2.1862.

Komariah, N. (2018). Implementasi fungsi manajemen pendidikan di sdi wirausaha indonesia. Jurnal Perspektif, 16(1), 107-112.

Kristiawan, M. (2017). Manajemen pendidikan. Yogyakarta: Budi Utama.

Lestari, I. (2015). Manajemen sarana dan prasarana di pendidikan anak usia dini. Jurnal Manajemen Pendidikan. 25(5), 376-382.

Milles, M. B., \& Huberman, A. M. (1992). Analisis data kualitatif: buku sumber tentang metode-metode baru. Jakarta: UIP.

Moleong, L, J. (2011) metodologi penelitian kualitatif. PT Remaja Rosdakarya.

Mulyani, A. (2012). Pengaruh kinerja kepala sekolah dan kinerja guru terhadap mutu pembelajaran pada smk sekabupaten purwakarta. Jurnal Administrasi Pendidikan, 14(1), 86-92.

Nur, D., Sari, A., Bafadal, I., Wiyono, B. B., \& Malang, U. N. (2018). Implementasi manajemen berbasis sekolah. Jurnal Administrasi dan Manajemen Pendidikan, 1(2), 213221.

Rukayat, Y. (2018). Kualitas pelayanan publik bidang administrasi kependudukan di kecamatan pasirjambu. Jurnal Ilmiah Magister Administrasi, 11(2).

Setiawan, D. F. (2016). Relevansi rencana pembelajaran dalam international standar organisation (iso) 9001:2008 terhadap rencana pembelajaran dalam standar proses sekolah menengah kejuruan (Smk). Jurnal Equilibria Pendidikan, 1(1), 13-26. 
Saebani., \& Ahmad, B. (2012). Ilmu pendidikan islam. Bandung: Pustaka Setia.

Sugiyono. (2010). Metode penelitian pendidikan pendekatan kuantitatif, kualitatif, dan $r \& d$. Bandung: Alfabeta.

Suharyadi, A., \& Jabar, C. S. A. (2016). Evaluasi program BSE (buku sekolah elektronik) di SMP negeri kota Yogyakarta. Jurnal Akuntabilitas Manajemen Pendidikan, 4(1), 33. https://doi.org/10.21831/amp.v4i1.7625

Sujarweni, V. W. (2014). Metode penelitian: Lengkap, praktis, dan mudah dipahami. Yogyakarta: Pustaka Baru Press.

Tafsir, Ahmad. (2010). Ilmu pendidikan dalam persepektif islam. Bandung: Remaja Rosdakarya.

Torlakson, T. (2011). A blueprint for great schools. California: State Superinten- dent of Public Instruction California Department of Education. 